\title{
Alfred Skorupka
}

\section{Polityka i problemy cywilizacyjne \\ w Ameryce Lacińskiej}

DOI: $10.35757 /$ CIV.2010.12.10

Bezpośrednia inspiracją do napisania tej pracy stała się lektura tych rozdziałów książki Zderzenie cywilizacji Samuela Huntingtona (1927-2008), w których autor dokonuje wyszczególnienia cywilizacji latynoamerykańskiej. Chociaż wielu uczonych uznaje, że cywilizacja zachodnia składa się $z$ trzech głównych elementów: Europy, Ameryki Północnej i Ameryki Łacińskiej, zdaniem przywołanego uczonego ten ostatni obszar ma jednak wyraźnie odrębna tożsamość w porównaniu $z$ krajami Zachodu ${ }^{1}$. Ameryka Łacińska przebyła drogę zupełnie odmienną od Europy i Ameryki Północnej; jej kultura jest korporacyjna, autorytarna. $Z$ historycznego punktu widzenia kraje latynoskie sa wyłącznie katolickie, chociaż nie da się wykluczyć, że sytuacja ta ulegnie zmianie. Cywilizacja latynoamerykańska zawiera w sobie kultury tubylcze, które w Stanach Zjednoczonych zostały skutecznie wykorzenione. Ponadto rozwój polityczny i ekonomiczny Ameryki Łacińskiej przebiegał całkiem odmiennie niż w państwach północnoatlantyckich.

Przedstawiona argumentacja wymaga głębszego rozważenia. Nie chodzi bowiem tutaj o sama tylko nazwę czy liczbę cywilizacji

Alfred Skorupka - doktor nauk humanistycznych w dziedzinie filozofii, adiunkt w Katedrze Zarządzania i Informatyki Politechniki Śląskiej w Gliwicach.

1 S. Huntington: Zderzenie cywilizacji, przekład H. Jankowska, Warszawskie Wydawnictwo Literackie Muza SA, Warszawa 2003, s. 56-57. 
na świecie, ale o rzecz znacznie istotniejszą. Mianowicie każda klasyfikacja wyznacza przede wszystkim określony sposób rozumienia cywilizacji, istniejących między nimi powiązań i różnic. Zależy nam na tym, aby ten sposób był jak najbardziej trafny i przejrzysty.

Zanim więc udzielimy własnej, hipotetycznej odpowiedzi na pytanie, czy mamy podstawy do wyróżnienia cywilizacji latynoamerykańskiej, warto zapoznać się bliżej z poglądami, jakie na ten temat sformułowali znani badacze: Oswald Spengler, Arnold Toynbee, cytowany już Samuel Huntington, Francis Fukuyama, Carlos A. Montaner, Mariano Grondona i Lawrence E. Harrison.

\section{Kultura nagle zamordowana przez faustowskiego czlowieka}

Historiozofia Oswalda Spenglera (1880-1936) ma charakter poetycki; sam jej twórca powiadał, że kultury - niczym rośliny i zwierzęta - należą do żywej natury (lebendige Natur) Goethego, nie zaś do martwej natury Newtona ${ }^{2}$.

Wczuwanie się, oglądanie, porównywanie, bezpośrednia pewność wewnętrzna, ściśle zmysłowa imaginacja - oto środki, za pomoca których zbliżał się do tajemnicy poruszających się zjawisk. Otóż są to środki badań historycznych jako takich - i nie ma żadnych innych ${ }^{3}$.

Mimo że Spengler nie był pierwszym historiozofem w dziejach myśli ludzkiej, uważał, że jego filozofia jest przełomowa ${ }^{4}$. Twierdził,

\footnotetext{
2 Por. O. Spengler: Zmierzch Zachodu. Zarys morfologii historii uniwersalnej, skrót dokonany przez H. Wernera, przekład J. Marzęcki, Wydawnictwo KR, Warszawa 2001, s. 41.

3 Ibidem, s. 44.

4 Por. A. Kołakowski: Spengler. Wiedza Powszechna, Warszawa 1981, s. 57-59: Wedle Spenglera sens i treść światu przemijających form nadaje zjawisko wielkich kultur. Dla niemieckiego historiozofa historia powszechna staje się więc historią wielkich kultur, a filozofia - filozofia kultury. Kultury zaś to organizmy, żywe ciała odrębnych dusz, realizacje ich możliwości. Jako żyjące organizmy maja one swe narodziny, rozkwit i zgon, zawarte w przedziale czasowym liczacym przecietnie tysiac lat. Kultury stanowia organizmy nie pozostajace ze soba w żadnym związku, wzajemnie nieprzenikliwe - można ustalać między nimi jedynie stosunki homologiczności czy jednoczesności. Każda kultura przechodzi przez te same sta-
} 
że dokonuje wręcz „przewrotu kopernikańskiego”; za „ptolemejski system historii" uważał przekonanie, że Europa-Zachód stanowi centrum całego historycznego „dziania się", podczas gdy inne kultury sa wobec nas podrzędne ${ }^{5}$.

[...] zastapienie go w tej ksiażce nowym systemem, w którym Starożytność i kultura zachodnia nie zajmuja żadna miara uprzywilejowanej pozycji wobec Indii, Babilonu, Chin, Egiptu, kultury arabskiej i meksykańskiej - odrębnych światów historycznego stawania się, które w całościowym obrazie dziejów maja równy ciężar gatunkowy, często przewyższając antyk wspaniałością duchowych koncepcji i potęga uniesień - uważam za kopernikański przewrót $\mathrm{w}$ sferze historii ${ }^{6}$.

Spengler wprawdzie niewiele miejsca poświęca omówieniu kultury meksykańskiej (Majów i Azteków), niemniej charakteryzuje jej znaczenie, osiagnięcia i doniosłość w sposób bardzo dobitny. Powiada, że wszystkie te państwa indiańskie wielkościa i posiadanymi środkami górowały znacznie nad państwami grecko-rzymskimi $z$ czasów Hannibala, $z$ całą swą górnolotna polityką, starannie zorganizowana skarbowościa, wypracowanym prawodawstwem, koncepcjami zarzadzania i tradycja gospodarcza (co zgoła nie mieściło się $\mathrm{w}$ głowach ministrów Karola V), $\mathrm{z}$ bogata wielojęzyczna literatura, wyrafinowaną i wytworna społecznościa wielkich miast - nie znajdująca wówczas żadnego odpowiednika na Zachodzie. $Z$ ogromnego miasta Tenochtitlan nie pozostał jednak kamień na kamieniu, a w prastarych lasach Jukatanu całe okazałe grono wielkich miast-państw Majów szybko padło ofiara bujnej tropikalnej roślinności

\footnotetext{
dia rozwoju, ma swoją wiosnę, lato, jesień i zimę czy też okres wstępny (Vorzeit), okres pełni rozkwitu i okres więdnięcia, czyli cywilizację.

Spengler wyróżnił także trzy dusze kultur: apollińską, właściwą kulturze antycznej, faustyczną, właściwą kulturze zachodnioeuropejskiej, oraz magiczną, właściwą Arabom i ogólnie religiom orientalnym. Za wyrazy duszy faustycznej uważał m.in. właśnie osobowość Fausta - wiecznie nienasyconego, nieukojonego i niespokojnie ku czemuś dażacego. Kolejna cecha duszy faustycznej jest postrzeganie przestrzeni jako nieskończenie głębokiej, bezgranicznej rozciagłości, a także samoświadomość, imperatyw moralny czy nawet los króla Leara.

5 Ibidem, s. 36-37.

6 Ibidem, s. 37

7 Ibidem, s. 276-277.
} 
Spengler pisze, że przedkultura cywilizacji meksykańskiej, która, tak jak w Egipcie i Chinach, wytworzyła pismo i kalendarz, jest już dla nas niepoznawalna. Meksykański człowiek niewątpliwie miał niezwykle silnie rozwinięty zmysł historyczny. Epoki kultury Majów i Azteków Spengler lokalizuje około 200 lat później niż epoki kultury arabskiej i jakieś 700 lat wcześniej niż epoki kultury zachodniej. Wczesny okres „helleńskich” państw Majów jest poświadczony przez datowane, zdobione reliefami filary starych miast: Copan, Tikal, Chichen Itza, Naranjo oraz Seibal (z lat 160-450). W końcu tego okresu Chichen Itza ze swymi budowlami stało się wzorcowym przykładem architektury na całe stulecia; oprócz niego przepysznie rozkwitały Palenque i Piedras Negras. Odpowiadałoby to naszemu późnemu gotykowi oraz renesansowi (lata 450-600, u nas 1250-1400). Lata 600-960 stanowia $z$ kolei okres, gdy Majowie wkraczaja w faze „hellenizmu”; około 960 roku zostało założone Uxmal, stając się wkrótce miastem światowym pierwszej rangi, tak jak założone także u progu cywilizacji światowej Aleksandria i Bagdad. Polityka spoczywała w rękach słynnej Ligi z Mayapan (960-1195), przymierza trzech czołowych państw, które, mimo zaciekłych wojen i kilkakrotnych rewolucji, jak się zdaje, umiały opanować sytuację (Starożytność - lata 350-150, Zachód 1800-2000) ${ }^{8}$.

Zakończenie tego okresu było naznaczone wybuchem wielkiej rewolucji; w zwiazku z tymi wydarzeniami „rzymskie” władze Nahua podjęły definitywną ingerencję w sprawy Majów. $Z$ ich pomoca $\mathrm{Hu}-$ nac Ceel dokonał generalnego przewrotu i zniszczył Mayapan (około 1190 roku, Starożytność - 150 rok p.n.e.). Kolejne wydarzenia stanowia typową historię dojrzałej cywilizacji, w której poszczególne ludy walcza o prymat militarny. Tymczasem na scenie dziejowej pojawił się najmłodszy $z$ tych ludów, Aztekowie, dzicy barbarzyńcy o nienasyconej woli mocy. Założyli oni w 1325 roku Tenochtitlan (Starożytność doby Augusta), które urosło wkrótce do rangi

\footnotetext{
8 Ibidem, s. 277-278.
} 
władczej stolicy całego meksykańskiego świata. Około 1400 roku rozpoczęła się militarna ekspansja w wielkim stylu; zdobyte tereny były obsadzane wojskowymi kolonistami i osnuwane siecia dróg wojskowych, a zależne państwa - dzięki wyższej sztuce dyplomacji - były utrzymywane w ryzach i wzajemnej izolacji. Imperialne Tenochtitlan rozrosło się niepomiernie i było zamieszkiwane przez kosmopolityczna ludność, mówiąca wszystkimi językami tego światowego mocarstwa. Nabierała tempa ofensywa w kierunku południowym i już szykowano się do zaanektowania państw Majów. Zachód znajdował się wtedy mniej więcej w fazie, którą Majowie już przebyli około 700 roku. Dopiero epoka Fryderyka Wielkiego byłaby na tyle dojrzała, aby zrozumieć politykę Ligi z Mayapan'.

Wtedy jednak nagle i szybko nastapił nieoczekiwany koniec ${ }^{10}$. Upadek wspaniałej i pod wieloma względami niepowtarzalnej kultury indiańskiej w Meksyku, Spengler oddaje przygnębiającymi słowami:

Kultura ta stanowi jedyny przykład gwałtownej śmierci. Nie zwiędła, nie zmarniała pod uciskiem ani nie uległa zahamowaniu, lecz w pełnym przepychu swego rozwoju została zamordowana, zniszczona tak jak słonecznik, którego głowę ściał jakiś przypadkowy przechodzień. [...] Wszystko to zostało zburzone nie przez jakąś desperacką wojnę, lecz unicestwione przez garstkę bandytów w kilka zaledwie lat, i to tak gruntownie, że nie zachowało się nawet $\mathrm{w}$ pamięci pozostałej przy życiu ludności [...].

Najstraszniejsze w tym widowisku jest to, że nie przynależało ono nawet do konieczności istnienia kultury zachodniej. Była to prywatna impreza awanturników, i nikt w Niemczech, Anglii czy Francji nie przeczuwał wtedy, co się tu właściwie dzieje. Jeśli gdziekolwiek na ziemi, to właśnie tu objawiło się, że historia ludzkości nie ma żadnego sensu, że głębokie znaczenie tkwi tylko w przebiegu życia poszczególnych kultur. Ich wzajemne stosunki sa bez znaczenia i maja charakter przypadkowy. Przypadek był tu tak strasznie banalny, tak wręcz śmieszny, że mógłby razić swą niestosownością w najnędzniejszej farsie"11.

\footnotetext{
9 Ibidem, s. 278-279.

${ }^{10}$ Niemiecki historiozof pisze także o zniszczeniu kultury peruwiańskiej, mając na myśli imperium Inków oraz poprzedzajace je społeczności indiańskie o wyższej kulturze (np. Chimu, Nazca, Tiahuanaco), jednak kultura ta nie została przez niego omówiona. Ibidem, s. 279. ${ }^{11}$ Ibidem, s. 276-277.
} 
Nie wszystkie intuicje Spenglera sa uzasadnione $z$ punktu widzenia dzisiejszej nauki. W Zmierzchu... znajdujemy liczne, śmiałe - „artystyczne” porównania między wydarzeniami czy zjawiskami odległymi zarówno w czasie, jak i w przestrzeni. Jeśli nawet niektóre $z$ owych analogii pozostają w określonym stopniu trafne, wobec większości z nich można wysuwać zastrzeżeń bez liku. Nie ma więc raczej sensu wnikliwe analizowanie tych koncepcji, wystarczy, że przytoczyliśmy już sposób myślenia niemieckiego filozofa - i po prostu pozostawiamy czytelnikowi decyzje, czy akceptuje taka wizję historii oraz perspektyw cywilizacji świata.

Istotna wszakże idea Spenglera dla prowadzonych analiz jest jego przekonanie o tym, że kolonizacja obu Ameryk przez Europejczyków nie spowodowała powstania nowej cywilizacji, ale jedynie rozszerzyła świat Zachodu kosztem społeczności indiańskich ${ }^{12}$.

\section{Społeczności indiańskie i europejska kolonizacja}

Arnold J. Toynbee (1889-1975) zdefiniował cywilizacje jako „najmniejsze jednostki studiowania historii”, gdyż schodzenie ku mniejszym od cywilizacji obiektom studiów historycznych uniemożliwia właściwe zrozumienie procesów dziejowych. Sformułował koncepcje „wyzwań i odpowiedzi” jako wartościowe narzędzie badania sił napędowych powodujących przemiany cywilizacyjne. Wykazywał też, że niezwykłe osiagnięcia cywilizacji zachodniej w ostatnich stuleciach pozwalaja traktować ja jako cywilizację obecnie globalna, majaca przesłanie i perspektywy odmienne od pozostałych cywilizacji. Wedle Toynbee'go najgłębsze rozumienie losu ludzkiego przedstawia nam nauka Jezusa. Jedynie przez odniesienie do Boga potrafimy właściwie zrozumieć samych siebie oraz świat, w którym żyjemy ${ }^{13}$.

\footnotetext{
12 Ibidem, s. 208.

${ }^{13}$ Por. A. Toynbee: Studium historii, skrót dokonany przez D.C. Sommervella, przekład J. Marzęcki, Państwowy Instytut Wydawniczy, Warszawa 2000, s. 720.
} 
Zdaniem Toynbee'ego Ameryka przed przybyciem hiszpańskich konkwistadorów wydała na świat cztery społeczności: andyjska, jukatańska, meksykańska oraz Majów. Społeczność andyjska w Peru osiagnęła już stan państwa uniwersalnego ${ }^{14}$, imperium Inków, gdy zniszczył ją w 1530 roku Pizarro. Społeczność meksykańska była bliska tego stanu, przy czym predestynowne do roli państwa uniwersalnego było imperium Azteków. Społeczność jukatańska na półwyspie Jukatan została wchłonięta przez społeczność meksykańska jakieś czterysta lat wcześniej, przed podbojem Tenochtitlan przez Cortésa. Obie te społeczności były usynowione przez wcześniejszą społeczność Majów, która osiagnęła, jak się zdaje, wyższy stopień cywilizacji niż jej sukcesorki. Dobiegła kresu - raptownie i tajemniczo - w VII wieku po Chrystusie, pozostawiajac po sobie świadectwo $\mathrm{w}$ postaci ruin wielkich miast $\mathrm{w}$ wilgotnych dżunglach Jukatanu. Społeczność ta celowała w astronomii, wykorzystywanej praktycznie $\mathrm{w}$ ramach nader ścisłego rytmu chronologicznego. Straszliwe obrzędy religijne odkryte przez Cortésa w Meksyku były zapewne niewybredna, zbarbaryzowana wersją dawnej religii Majów ${ }^{15}$.

Wyzwaniem, na które odpowiedź stanowiła cywilizacja Majów, była niezwykła bujność tropikalnych lasów. Co ważne, żadna tego rodzaju cywilizacja nigdy nie wyłoniła się już ze stanu dzikości w podobnych warunkach nad Amazonka czy Kongiem. Cywilizacja jukatańska była $\mathrm{z}$ kolei wystawiona $\mathrm{w}$ toku swej genezy na wyzwanie ze strony bezwodnego, bezdrzewnego i prawie wyzbytego gleby wapiennej szelfu Półwyspu Jukatańskiego, cywilizacja meksykańska zaś - na wyzwanie płaskowyżu meksykańskiego. Cywilizacja (lub też cywilizacje), która powstała w Ameryce Połu-

\footnotetext{
${ }^{14}$ Państwo uniwersalne (np. Cesarstwo Rzymskie) powstaje w okresie dezintegracji danej cywilizacji i ma za zadanie powstrzymać rozkład społeczności, czego jednak nie potrafi dokonać. Państwa uniwersalne daja jedynie „złudzenie nieśmiertelności”, a poza tym wytwarzaja wiele użytecznych instytucji, wspólnych dla dużego obszaru: usprawniaja komunikację, ujednolicaja język, pismo, prawo, itp. Kościoły uniwersalne $z$ kolei pełnia podobna rolę jak państwa uniwersalne w danej społeczności, jednak w odniesieniu do religii. W czasach upadku Cesarstwa Rzymskiego jego Kościół uniwersalny stanowiło chrześcijaństwo.

15 Por. A. Toynbee: Studium..., s. 46-47.
} 
dniowej, stanowiła odpowiedź na dwa całkiem odmienne wyzwania: ze strony płaskowyżu andyjskiego oraz przyległego wybrzeża Pacyfiku. Na płaskowyżu występuje posępny klimat i nieurodzajna gleba; na wybrzeżu zaś - upał i susza prawie bezdeszczowych pustynnych terenów równikowych na poziomie morza. Pionierzy nadbrzeżnej cywilizacji wyczarowali swe oazy z pustyni, gospodarując oszczędnie skapa ilością wody spływającej z zachodniej skarpy płaskowyżu i ożywiając równiny systemem irygacji. Pionierzy na płaskowyżu przeobrazili natomiast górskie stoki w pola uprawne, oszczędnie gospodarując skapa warstwa gleby na terenach chronionych przez wszechobecny system pracowicie budowanych murów retencyjnych ${ }^{16}$.

Cywilizacja Majów nigdy nie wykroczyła w swym rozwoju poza epokę kamienna, podczas gdy usynowione cywilizacje meksykańska i jukatańska dokonały godnego uwagi postępu w obróbce różnych metali $\mathrm{w}$ ciagu pięciuset lat przed hiszpańskim podbojem. Nie ulega jednak watpliwości, że społeczność Majów stworzyła o wiele świetniejszą cywilizację niż owe dwie drugorzędne społeczności przez nią usynowione. Zdumiewajace sa zastosowania astronomicznej matematyki w tak wczesnej społeczności, jaką byli Majowie; w ogromnym, liczącym 374440 lat, makrocyklu zazębiało się ze sobą co najmniej dziesięć odrębnych cykli składowych. Ten niezwykle ścisły, choć także złożony, kalendarz Majów został przekazany przez „Stare Państwo” społecznościom jukatańskiej i meksykańskiej. Natomiast u Inków wyjątkowe było utrzymywanie niemal totalitarnego reżimu bez pomocy jakiegokolwiek systemu notacji, poza bezsłowna semantyką kipu. Poza tym ci „Rzymianie Andów" utrwalali swe podboje za pomoca sieci dróg; toteż urzędowa wiadomość mogła wędrować z Cusço do Quito - odległość wynosząca w linii powietrznej przeszło tysiąc mil i być może o połowę więcej gościńcem - zaledwie dziesięć dni ${ }^{17}$.

${ }^{16}$ Ibidem, s. 81-82, 85, 86-87.

17 Ibidem, s. 180, 499, 517, 526. 
Społeczność andyjska padła od uderzenia hiszpańskich konkwistadorów; jest prawdopodobne, iż gdyby ludy świata zachodniego nigdy nie przeprawily się przez Atlantyk, państwo Inków mogłoby trwać kilka stuleci dłużej. Zagłada imperium Inków nie jest jednak tym samym co załamanie cywilizacji andyjskiej, ponieważ załamanie to nastapiło znacznie wcześniej, a militarny i polityczny rozkwit Inków w stuleciu poprzedzającym podbój hiszpański (nie będąc bynajmniej identyczny $z$ rozkwitem kulturalnym cywilizacji andyjskiej) był w rzeczywistości późnym epizodem w jej upadku. Cywilizacja meksykańska natomiast padła pod naporem konkwistadorów we wcześniejszej fazie, gdy imperium Azteków, choć już jawnie predestynowane do roli państwa uniwersalnego swej społeczności, nie zakończyło jeszcze podbojów. Możemy wyrazić tę różnicę mówiąc, że społeczność andyjska została podbita w swej epoce Antoninów, meksykańska zaś w swej epoce Scypionów. Jednak „epoka Scypionów” jest fazą okresu zaburzeń i stanowi $z$ samej definicji ciag dalszy uprzedniego załamania ${ }^{18}$.

Wedle Toynbee'go pozostaje otwarte pytanie, czy społeczności indiańskie odrodzą się jeszcze w przyszłości w tej czy w innej postaci. Na przykład po rewolucji w roku 1910 w Meksyku, nagle ożyła, jak się okazało, nie pogrzebana, lecz jedynie uśpiona w śnie zimowym, miejscowa społeczność i przebiła się przez kulturową skorupę, nałożona jej przez Kastylijczyków. Może się więc okazać, że widome podboje kulturowe dokonywane przez zachodnie chrześcijaństwo $\mathrm{w}$ andyjskim świecie i w innych stronach zostana uznane - wcześniej czy później - za coś powierzchownego i przejściowego ${ }^{19}$.

Chociaż Toynbee wymienia aż cztery cywilizacje indiańskie, nie stwierdza jednak, aby, po odkryciu Ameryki przez Kolumba, przybywający do Nowego Świata Europejczycy stworzyli tutaj nowa cywilizację. Kolonizatorzy z Hiszpanii, Portugalii czy Anglii po prostu zdobywali nowe tereny dla cywilizacji zachodniej. Angielski uczony pisze jedynie o dużych różnicach kulturowych między poszczególny-

${ }^{18}$ Ibidem, s. 244-245

19 Ibidem, s. 498. 
mi grupami kolonizatorów oraz - co zrozumiałe - w konsekwencji, o odmiennym charakterze kulturowym poszczególnych kolonii.

Triumfatorami w rywalizacji między różnymi grupami kolonizatorów o opanowanie Ameryki Północnej stali się mieszkańcy Nowej Anglii (chodzi tutaj głównie o mieszkańców stanów Massachusetts, Connecticut i Rhode Island) ${ }^{20}$. Oni to właśnie wyparli $z$ tej części świata Hiszpanię, Holandię i Francję. Następnie, po wojnie secesyjnej, Północ zatriumfowała także nad stanami południowymi. Mieszkańcy Nowej Anglii stali się więc panami całego wybrzeża Pacyfiku - od Seattle do Los Angeles. Toynbee sporo miejsca poświęca analizom wyzwań ze strony środowiska geograficznego, którym musiały sprostać grupy kolonizatorów; zważywszy je wszystkie - glebę, klimat, uniedogodnienia transportowe i cała resztę - nie sposób zaprzeczyć, że pierwotna kolonialna siedziba mieszkańców Nowej Anglii była najtrudniejszą ze wszystkich kraina. Tak więc historia północnoamerykańska przemawia na rzecz twierdzenia: im większy stopień trudności, tym silniejszy bodziec do rozwoju dostaja jej mieszkańcy, w rezultacie czego dystansuja sąsiadów i wreszcie zapanowuja nad nimi ${ }^{21}$.

\section{Przesłanki istnienia cywilizacji latynoamerykańskiej. Pro i contra}

Wyróżnienie cywilizacji latynoamerykańskiej przez Samuela Huntingtona ${ }^{22}$, wynika ściśle $z$ przyjętej przez niego koncepcji cy-

\footnotetext{
${ }^{20}$ Por. ibidem, s. 89-90, 100-103, 141-143.

${ }^{21}$ Podobne rozważania do tych na temat geograficznych czynników stymulujących rozwój osadnictwa w Ameryce Północnej czyni również Toynbee w odniesieniu do Ameryki Południowej, regionów: Brazylia - La Plata - Patagonia. Por. ibidem, s. 142.

${ }_{22}$ Po upadku komunizmu stracił znaczenie podział na świat pierwszy, drugi i trzeci. Amerykański politolog dowodzi wiec, że polityke światowa zdominowały teraz zderzenia miedzy cywilizacjami. Ani ideologie, ani gospodarka nie sa już źródłami konfliktów międzynarodowych. Stają się nimi różnice kulturowe, wywodzące się w znacznej mierze $z$ podziałów religijnych i przesadzające o tożsamości narodów. Dlatego główna teza książki Huntingtona brzmi: kultura i tożsamość kulturowa, będące w szerokim pojęciu tożsamością cywilizacji, kształtuja wzorce spójności, dezintegracji i konfliktu w świecie, jaki nastał po zimnej wojnie. Osia po-
} 
wilizacji. Autor Zderzenia cywilizacji stworzył teorię politologiczna, w której założył, że w każdej cywilizacji istnieja państwo - ośrodek główny (core state) danej społeczności oraz państwa członkowskie (member states) - uznajace zwykle przewodnictwo tego najważniejszego, a także wyznajace podobna religię i wartości ${ }^{23}$. Jako polito$\log$, Huntington w swej teorii akcentuje głównie cechy cywilizacji $\mathrm{z}$ punktu widzenia przemian politycznych $\mathrm{w} X \mathrm{XX}$ wieku, natomiast zdaje się bagatelizować podobieństwa kulturowe istniejące między państwami czy uogólnienia historiozoficzne dotyczące "dusz” poszczególnych narodów i ludów.

Ameryka Łacińska - podobnie jak cywilizacja islamska oraz postulowana również przez Huntingtona cywilizacja afrykańska - nie maja jednak państw-ośrodków, co w pewnej mierze jest skutkiem imperialistycznej polityki mocarstw zachodnich, które wcześniej podzieliły między sobą te regiony na tak zwane strefy wpływów $^{24}$. Jeśli chodzi o Amerykę Łacińska, można sobie wyobrazić, że takim państwem-ośrodkiem cywilizacji hiszpańskojęzycznej mogłaby być Hiszpania, ale jej przywódcy świadomie wybrali członkostwo w cywilizacji europejskiej, podtrzymujacc jednocześnie kontakty kulturalne $z$ byłymi koloniami. Obszar, zasoby, liczba ludności, potencjał militarny i gospodarczy predysponowałby Brazylię do roli lidera Ameryki Łacińskiej, jednak kraj ten odgrywa w tej części świata rolę podobna do tej, jaka pełni Iran w cywilizacji islamskiej. Chociaż oba państwa maja skądinąd wszelkie dane ku temu, aby stać się ośrodkami cywilizacji, utrudniają to różnice subcywilizacyjne (w wypadku Brazylii - językowe, w wypadku Iranu - religijne).

W Ameryce Łacińskiej jest więc kilka państw - Brazylia, Meksyk, Wenezuela i Argentyna - które współdziałają, a zarazem rywalizuja

lityki światowej jest obecnie interakcja między potęga i kulturą Zachodu a potęga i kultura pozostałych cywilizacji. Świat, jaki się wyłonił po upadku komunizmu jest więc światem siedmiu lub ośmiu wielkich cywilizacji; sa to cywilizacje: zachodnia, latynoamerykańska, prawosławna, afrykańska, islamska, hinduistyczna, buddyjska, chińska i japońska. Por. S. Huntington: Zderzenie..., s. 15-51.

23 Ibidem, s. 218-220.

${ }^{24}$ Ibidem, s. 219-220. 
o przywództwo. Sytuację na tym obszarze komplikuje dodatkowo fakt, że Meksyk podjął próbę przedefiniowania swojej tożsamości $z$ latynoamerykańskiej na północnoamerykańska, a Chile i inne państwa moga pójść w jego ślady. Huntington konkluduje zatem, że cywilizacja latynoamerykańska prawdopodobnie połączy się $\mathrm{w}$ końcu $\mathrm{z}$ zachodnia i stanie się jednym $\mathrm{z}$ jej trzech odgałęzień.

Wśród cech charakterystycznych cywilizacji zachodniej, które odróżniaja ją od innych społeczności, Huntington wymienia dziedzictwo starożytności klasycznej, katolicyzm i protestantyzm, języki europejskie, rozdział władzy duchowej i doczesnej, rzady prawa, pluralizm społeczny, gremia przedstawicielskie oraz indywidualizm $^{25}$. Cechy te jednak charakteryzuja również kraje latynoamerykańskie i, w równym stopniu jak Europę i Stany Zjednoczone - odróżniaja je wszystkie od tych cywilizacji, w których dominuja prawosławie, islam lub konfucjanizm. Opierając się więc na samej teorii autora Zderzenia cywilizacji, niełatwo jest wymienić różnice cywilizacyjne między Ameryką Północną a Południową. Nie zmienia to oczywiście $\mathrm{w}$ niczym faktu występowania silnego poczucia odrębności między analizowanymi obszarami. Więzi i pokrewieństwo cywilizacyjne nie sa bowiem zawsze najmocniejszymi siłami łączącymi ze soba państwa. Wręcz przeciwnie, nierzadko się zdarza, że największa rywalizacja i najbardziej krwawe wojny wybuchaja między sąsiadami - państwami należącymi do tej samej społeczności (na przykład w Europie druga wojna światowa lub w Azji tak zwana druga wojna chińsko-japońska).

Francis Fukuyama, kolejny wybitny amerykański uczony, podobnie jak Huntington podkreśla, że kapitalizm nigdy nie sprawdził się w Ameryce Łacińskiej oraz w innych regionach Trzeciego Świata, bo też nigdy nie został tam na poważnie wypróbowany ${ }^{26}$. Innymi słowy, większość rzekomo „kapitalistycznych” gospodarek

\footnotetext{
25 Ibidem, s. 100-105.

${ }^{26}$ F. Fukuyama: Koniec historii, przekład. T. Bieroń, M. Wichrowski, Wydawnictwo Zysk i S-ka, Poznań 1996, s. 157-159. Więcej analiz tego autora na temat gospodarek latynoamerykańskich por. ibidem, s. 148-162.
} 
w Ameryce Łacińskiej jest paraliżowana przez tamtejsze tradycje merkantylistyczne i rozbudowany sektor państwowy, powołany w imię sprawiedliwości ekonomicznej. Podczas gdy Ameryka Północna odziedziczyła filozofię, tradycje i kulturę liberalnej Anglii, Ameryka Łacińska przyswoiła sobie wiele instytucji feudalnych XVII- i XVIII-wiecznej Hiszpanii i Portugalii. Należało do nich zamiłowanie korony hiszpańskiej i portugalskiej do kontroli działalności gospodarczej w celu przysporzenia sobie chwały (tj. merkantylizm). W Ameryce Łacińskiej powszechna praktyka stało się wykorzystywanie władzy politycznej do promowania interesów klas wyższych, wzorujących się na dawnych „próżniaczych” klasach ziemskich w Europie, a nie na bardziej przedsiębiorczej klasie średniej, która powstała w Anglii i Francji.

W książce Zderzenie cywilizacji nieco głębsze analizy zostaja poświęcone Meksykowi ${ }^{27}$. Wedle amerykańskiego uczonego Meksyk (podobnie jak Turcja) ma kulturę wybitnie niezachodnią. W XIX wieku Meksyk, podobnie jak imperium osmańskie, został rozczłonkowany rękoma ludzi Zachodu. W latach dwudziestych i trzydziestych XX wieku też przetoczyła się przezeń rewolucja, która stworzyła nowa podstawę tożsamości narodowej oraz nowy, jednopartyjny system polityczny. W Meksyku, podobnie jak w Ro$\mathrm{sji}$, w trakcie rewolucji przyswojono i zaadaptowano pewne elementy kultury zachodniej, co zrodziło nowy nacjonalizm, wrogi kapitalizmowi i demokracji Zachodu. Turcja przez sześćdziesiąt lat próbowała się określić jako kraj europejski, Meksyk natomiast starał się określić swoją tożsamość w opozycji wobec Stanów Zjednoczonych.

Zmiana nastapiła $\mathrm{w}$ latach osiemdziesiątych, gdy prezydent Miguel de la Madrid zaczął, a jego następca, prezydent Carlos Salinas de Gortari kontynuował politykę całkowitej redefinicji celów, zwyczajów i tożsamości kraju. Od czasu rewolucji 1910 roku była to najbardziej istotna zmiana. Salinas stał się meksykańskim

\footnotetext{
${ }^{27}$ Por. S. Huntington: Zderzenie..., s. 245-246.
} 
Mustafą Kemalem Atatürkiem. Ten ostatni propagował w Turcji sekularyzm i nacjonalizm, prądy dominujace w owym czasie na $\mathrm{Za}$ chodzie, Salinas - liberalizm gospodarczy, jedną z dwóch doktryn przeważajacych na Zachodzie w jego epoce (nie przyjał drugiej, czyli demokracji politycznej). Tak jak w kraju Atatürka, poglądy te zostały przyjęte przez elity polityczne i gospodarcze. Salinas zdołał znacznie obniżyć inflację, sprywatyzował bardzo wiele przedsiębiorstw sektora publicznego, popierał inwestycje zagraniczne, obniżył cła i subsydia, dokonał restrukturyzacji zadłużenia zagranicznego, przeciwstawił się potężnym związkom zawodowym, zwiększył produktywność i wprowadził Meksyk do NAFTA, do której należą Stany Zjednoczone i Kanada. Celem reform Atatürka była przemiana Turcji $z$ bliskowschodniego kraju muzułmańskiego w świecki kraj europejski, reformy Salinasa zmierzały do przekształcenia Meksyku z kraju latynoamerykańskiego w północnoamerykański.

Nie była to dla Meksyku jedyna, nieunikniona opcja. Elity tego kraju mogły przecież kontynuować kurs antyamerykański i „trzecioświatowy" i dalej prowadzić polityke protekcjonizmu. Jednak przeważająca większość politycznych, gospodarczych i intelektualnych elit kraju opowiada się za zbliżeniem ze Stanami Zjednoczonymi i NAFTĄ; co więcej, w odróżnieniu od sytuacji, w jakiej znajduje się Turcja, większość elit cywilizacji docelowej także popiera transformację kulturowa Meksyku. Stany Zjednoczone i Meksyk dzieli ponadto znacznie mniejszy dystans kulturowy niż Turcję i Europę, przede wszystkim ze względu na religię. Niemniej w 1995 roku prozachodnia postawa Meksyku nie została jeszcze poddana testowi demokracji. Noworoczna indiańska rewolta w Chiapas spotkała się $z$ dużym zrozumieniem ze strony wielu rodzimych intelektualistów i dziennikarzy. Prezydent Salinas całkiem świadomie przyznał bowiem reformie gospodarczej i westernizacji priorytet przed reforma polityczna i demokratyzacja. Tymczasem zarówno rozwój gospodarczy, jak i coraz bliższe związki ze Stanami Zjednoczonymi wzmacniaja siły domagające się prawdziwej demokratyzacji systemu politycznego. Czy amerykanizacja Meksyku jest do pogodzenia 
z demokratyzacja? ${ }^{28}$ - to pytanie, na które elity i społeczeństwo tego państwa, jak się zdaje, wciąż szukają odpowiedzi, broniąc sie przed pokusa autorytaryzmu, tak dobrze znanego w innych krajach Ameryki Łacińskiej.

Huntington wymienia następujace patologie życia społecznego trapiące Stany Zjednoczone i państwa europejskie: narastanie zachowań antyspołecznych, rozkład rodziny, zanik „kapitału społecznego", ogólny upadek „etosu pracy” i kult folgowania własnym potrzebom, spadek zainteresowania nauka oraz aktywnościa intelektualną, a także słabnięcie chrześcijaństwa ${ }^{29}$. Wszystkie te problemy, które stanowia tak wielkie wyzwanie dla elit politycznych krajów Zachodu, występuja także, często nawet na większa skalę, w krajach Ameryki Łacińskiej. Toteż programy i różne metody społecznego uzdrawiania czy nawet „odradzania się Zachodu” powinny również interesować przywódców latynoamerykańskich. W Ameryce Łacińskiej istnieje między innymi duże rozwarstwienie społeczne, pauperyzacja znacznych grup ludności (zwłaszcza indiańskiej), bezwzględne i wpływowe lokalnie bandy handlarzy narkotyków oraz paramilitarne partyzantki. Wszystkie te czynniki powoduja, że takie zjawiska jak nędza, przemoc, okrucieństwo, rozkład rodziny czy brak edukacji są w tej części świata aż nazbyt dobrze widoczne.

Zastanawiając się nad przyszłościa Zachodu, Huntington nawiąuje do modelu periodyzacji ewolucji cywilizacji przedstawionego przez Carrolla Quigleya ${ }^{30}$. Na poczatku lat sześćdziesiątych $\mathrm{XX}$ wieku badacz ten wykazywał, że przesłanką rozwoju cywilizacji jest posiadanie „instrumentu ekspansji”, czyli organizacji militarnej, religijnej, politycznej lub gospodarczej zdolnej do akumulowania nadwyżki i jej inwestowania w produktywne innowacje. Cywilizacje zaczynają chylić się ku upadkowi, kiedy przestaje

\footnotetext{
28 Ibidem, s. 246-248.

${ }^{29}$ Ibidem, s. 536-537.

${ }^{30}$ Quigley opracował wspólny dla wszystkich cywilizacji model rozwoju, składajacy się $z$ siedmiu faz: skrzyżowanie (mixing), okres ciąży (gestation), ekspansja, epoka konfliktu, imperium światowe, schyłek i obca inwazja. Por. ibidem, s. 52.
} 
się wykorzystywać nadwyżkę w celach innowacyjnych, to znaczy gdy obniża się stopa inwestycji. Wówczas nadwyżka przeznaczana jest na konsumpcje, nie służąc rozwojowi efektywnych metod produkcji. Ludzie przejadaja nagromadzony kapitał, a cywilizacja ze stadium państwa uniwersalnego wkracza w faze rozkładu ${ }^{31}$. W połowie lat dziewięćdziesiątych Zachód wykazywał wiele cech typowych, według Quigleya, dla cywilizacji dojrzałej, wkraczającej w stadium rozkładu. Pod względem ekonomicznym był o wiele zamożniejszy niż jakakolwiek inna cywilizacja, ale wskaźniki wzrostu gospodarczego, oszczędności i inwestycji miał niskie, zwłaszcza $\mathrm{w}$ porównaniu $z$ krajami Azji Południowo-Wschodniej.

Zachód ma już za soba pierwsza, europejską fazę rozwoju i konsumpcji, która trwała kilka stuleci, a także fazę amerykańska, która przypadła na wiek XX. Zdaniem Huntingtona, jeśli Ameryka i Europa dokonaja odnowy moralnej, znajda oparcie we wspólnych cechach kulturowych oraz rozwina formy ścisłej integracji ekonomicznej i politycznej, uzupełniając współpracę na rzecz bezpieczeństwa w ramach NATO, moga dać poczatek trzeciej, euroamerykańskiej fazie rozkwitu gospodarczego i wpływów politycznych. Ścisła integracja polityczna zdołałaby do pewnego stopnia zrównoważyć względne zmniejszenie udziału Zachodu w światowej produkcji, produkcie gospodarczym i potencjale militarnym, a w konsekwencji odrodzić potęgę Zachodu w opinii przywódców innych cywilizacji. Konfederacja EU-NAFTA dyktowałaby warunki reszcie świata. Jednak tego rodzaju ewentualna polityczna i gospodarcza integracja Zachodu wiąże się przede wszystkim z tym, czy Stany Zjednoczone potwierdzą swoją zachodnia tożsamość oraz przyjmą rolę lidera zachodniej cywilizacji w skali globalnej ${ }^{32}$.

$Z$ przytoczonych powyżej rozważań Huntingtona wynika więc, że przyszłość Zachodu jest uzależniona od pogłębienia integracji między Stanami Zjednoczonymi i Unią Europejską w celu przeciwstawienia się światowej dominacji innych cywilizacji. Pisząc jednak

Ibidem, s. 534

32 Ibidem, s. 543-544. 
również o konfederacji EU-NAFTA, autor Zderzenia cywilizacji zdaje się sugerować, iż zacieśnienie współpracy ze Stanami Zjednoczonymi i krajami europejskimi leży także w interesie Ameryki Łacińskiej (bo przecież Meksyk należy już do NAFTA). Jakkolwiek nieufność i wrogość między Stanami Zjednoczonymi a Kuba (czy ostatnio także Wenezuelą) wydaje się nieprzekraczalna, brak porozumienia między państwami w tej części świata najpewniej spowoduje, iż niektóre $z$ nich wejdą $w$ ścisłą strefę wpływów Rosji lub Chin. A taka sytuacja, w ostatecznym rozrachunku, może się okazać, na przykład dla Kuby, bardziej niekorzystna niż jakieś formy współdziałania $z$ sąsiadami, znacznie bliższymi jej $z$ cywilizacyjnego punktu widzenia.

\section{Różne cywilizacje czy zapóźnienia społeczno-gospodarcze?}

W dyskusji o cywilizacyjnym charakterze Ameryki Łacińskiej powołamy się jeszcze na rozważania Carlosa A. Montanera - znanego pisarza i publicysty, urodzonego w 1943 roku w Hawanie, który jednak wyemigrował $z$ Kuby $w$ latach sześćdziesiatych i jest zdeklarowanym przeciwnikiem reżimu Castro, a także wręcz apologeta liberalnej demokracji ${ }^{33}$. Zdaniem tego badacza kraje latynoamerykańskie cierpią już od dawna na psychozę maniakalno-depresyjna na punkcie swojej pozycji politycznej. Czasami pod wpływem euforii media zgodnie ogłaszaja, że kontynent nareszcie osiagnał dojrzałość, lecz wkrótce potem mamy zwykle do czynienia $z$ kompletnym krachem na poziomie instytucjonalnym (zamachy stanu, hiperinflacja, odpływ kapitału, itp.). Skoro euforia tak szybko przeradza się tutaj w depresję i rozpacz - kulturę Ameryki Łacińskiej można określić jako cyklofreniczną.

${ }^{33}$ Por. C.A. Montaner: Latynoamerykańskie elity - kultura i zachowania, w: L.E. Harrison, S. Huntington (red.): Kultura ma znaczenie: jak wartości wpływaja na rozwój społeczeństw, przekład S. Dymczyk, Wydawnictwo Zysk i S-ka, Poznań 2003, s. 116-126. 
Do wielu wcześniejszych prób wyjaśnienia porażek krajów latynoamerykańskich na tle sukcesu Kanady i Stanów Zjednoczonych $^{34}$ Montaner dodaje jeszcze swoje własne rozwiązanie, mianowicie problem dostrzega w elitach stojących na czele głównych grup społecznych, lecz działających niekoniecznie dla dobra ogółu. W tym kontekście badacz wymienia sześć elitarnych grup: polityków, wojskowych, biznesmenów, duchownych, intelektualistów oraz przedstawicieli lewicy. Niewatpliwie elity stanowia jedynie odzwierciedlenie całego społeczeństwa, dlatego spychanie na nie całej winy jest zabiegiem nie do końca sprawiedliwym; niemniej, jak się zdaje, jedynie poprzez przemianę elitarnych grup możliwa stanie się odnowa i uzdrowienie społeczeństw Ameryki Łacińskiej.

Najważniejsze spostrzeżenia Montanera przytaczam poniżej. Politycy $\mathrm{w}$ państwach latynoamerykańskich sa do tego stopnia zdyskredytowani, że ubiegając się o wybór do parlamentu, udaja wręcz, że nie sa wcale politykami, ale raczej specjalistami $z$ innych dziedzin życia społecznego. W Ameryce Łacińskiej korupcja $\mathrm{w}$ sektorze publicznym stała się niemal normą, toteż ludzie nie wiążą $z$ politykami zbyt dużych nadziei na „lepsze jutro”, ci ostatni zaś nie potrafia (lub też nie chca) zmienić swych postaw i przyzwyczajeń. Wojsko natomiast, zamiast strzec państwa przed zewnętrznymi zagrożeniami, często podejmuje się misji ocalenia narodu przed błędami polityków, siłą wprowadzając w życie wojskowa wizje sprawiedliwości społecznej. Uwikłanie wojska w sprawy przemysłu kosztuje Amerykę Łacińską mnóstwo potężnych błę-

\footnotetext{
${ }^{34}$ Jedna $z$ owych prób wyjaśniania porażek krajów latynoamerykańskich jest tzw. teoria dependencji/uzależnienia (teoria de la dependencia), która nadała intelektualna spójność samookreśleniu się Południa jako całości przeciwko bogatej, uprzemysłowionej Północy. Głównym propagatorem tej teorii był argentyński ekonomista Raul Prebisch, który twierdził, że ślimacze tempo rozwoju regionów Trzeciego Świata wynika $z$ ogólnoświatowego kapitalistycznego ładu gospodarczego, który utrzymuje te regiony w stanie nieprzerwanego „uzależnionego rozwoju". Programy polityczne, które wyrosły z teorii uzależnienia były wybitnie nieliberalne. Chociaż teoria ta jest wciąż żywa pośród lewicowych intelektualistów, została zdyskredytowana jako model teoretyczny przez ogromnej skali zjawisko, którego nie umie wyjaśnić: przez rozwój gospodarczy Dalekiego Wschodu (a zwłaszcza Azji Południowo-Wschodniej) w okresie powojennym. Por. F. Fukuyama: Koniec historii..., s. 148-153.
} 
dów, kryzysów i zapaści gospodarczych, tym bardziej że oficerowie, podobnie jak politycy, również nie oparli się pokusie korupcji.

$\mathrm{Na}$ świat biznesu składaja się $\mathrm{w}$ tej części Ameryki przede wszystkim ostrożni spekulanci, nie zaś prawdziwi przedsiębiorcy - ludzie sukcesu nastawieni na ryzyko i inwestycje. Montaner zgadza się z pesymistycznym poglądem, że kraje Ameryki Łacińskiej, poza kilkoma wyjątkami, nigdy nie doczekały się powstania na swoim terenie nowoczesnego kapitalizmu, który szedłby w parze $z$ demokratycznym systemem politycznym. Ponadto znaczna część duchowieństwa opowiada się w ogóle przeciw gospodarce rynkowej, a nawet usprawiedliwia antydemokratyczne działania władz. Niepokój i krytykę budzą u księży, zdaniem Montanera, nawet takie regulacje gospodarcze, których spełnienia domagaja się bogate państwa europejskie od kandydatów do Unii Europejskiej. Duchowni związani $z$ teologia wyzwolenia wyrządzaja również duża szkodę, całkowicie potępiając motywację wynikająca $z$ chęci zysku, konkurencję i konsumeryzm.

Do wysoce niezadowalającego stanu społeczno-gospodarczego krajów latynoamerykańskich przyczyniła się też grupa rodzimych intelektualistów, którzy zreszta zajmuja wyjątkowo eksponowana pozycję w tej części świata. Kiedy jakiś pisarz albo artysta zdobędzie sławę, automatycznie staje się ekspertem we wszystkich sprawach. Korzystając ze swej popularności, owi intelektualiści często wypowiadaja się, nawet bez zastanowienia i kompetencji, także na tematy ekonomiczne. Wielu $z$ nich jest nastawionych wrogo wobec Zachodu, jankesów, wolnego rynku, a ponadto wieści nadejście powszechnej rewolucji. Wszystkie te opinie i fobie staja się głównym tworzywem latynoamerykańskiego obrazu świata. Ponadto większość publicznych i prywatnych uczelni w Ameryce Łacińskiej to ostoje archaicznych poglądów marksistowskich. Wreszcie w skład ostatniej kategorii napiętnowanej przez Montanera wchodzi tak zwana lewica, przez która autor rozumie związki zawodowe oraz tak zwanych rewolucjonistów. Związki zawodowe sprzeciwiaja się prywatyzacji przedsiębiorstw państwowych, od wielu dziesięcio- 
leci marnotrawiących środki publiczne oraz oferujacych wadliwe bądź nieistniejące dobra i usługi. Rewolucjoniści, dla których niemal świętym patronem jest Che Guevara, uważaja $z$ kolei, że maja prawo stosować przemoc polityczną bez względu na konsekwencje swych czynów; ich orężem sa strajki studenckie, uliczne zamieszki, sabotaż, porwania, zamachy bombowe i ataki partyzanckie.

Chociaż, zdaniem Montanera, nie ulega wątpliwości, że wymienione wyżej elity nie wyczerpuja listy winowajców, którzy pogrążyli Amerykę Łacińską w ubóstwie i niesprawiedliwości, to jednak tworzą one ich reprezentatywny przekrój. Elity - w każdym kraju - powinny się stać siłami propagujaccymi rzeczywisty postęp cywilizacyjny, zwłaszcza w imieniu grup najbardziej potrzebujacych. Dlatego bez zmiany mentalności dzisiejszych elit latynoamerykańskich nie sposób sobie wyobrazić rozwoju i pomyślności tej części swiata.

\section{Konkluzje}

$\mathrm{Na}$ koniec wypada jeszcze przedstawić własne stanowisko. Opierając się na analizach między innymi Oswalda Spenglera i Arnolda J. Toynbee'ego, skłaniam się ku twierdzeniu, że Ameryka Łacińska $z$ historiozoficznego punktu widzenia nie stanowi cywilizacji latynoamerykańskiej, jak chce Samuel Huntington. W Brazylii, Meksyku czy Peru mamy do czynienia z cywilizacja zachodnia, chociaż, bez watpienia, region ten kulturowo pod wieloma względami odstaje od Stanów Zjednoczonych i państw Unii Europejskiej.

Jak dowodza przeprowadzone rozważania, odmienność Ameryki Łacińskiej w porównaniu ze znacznie zamożniejszymi krajami świata zachodniego wynika przede wszystkim $z$ wielu zapóźnień politycznych, społecznych i gospodarczych, które po dziś dzień utrudniaja, a nawet uniemożliwiaja wzrost dochodu narodowego czy podniesienie poziomu materialnego i edukacyjnego milionów mieszkańców tej części świata. 
Przywołani tutaj uczeni - między innymi Samuel Huntington, Carlos A. Montaner i Francis Fukuyama - uważaja, że przyszłość państw latynoamerykańskich musi być związana $z$ konsekwentnymi, liberalnymi reformami gospodarczymi, które pozwola temu regionowi wyrwać się $z$ biedy i stagnacji. Możemy tutaj nawiązać jeszcze do analiz Mariano Grondony i Lawrence'a E. Harrisona, którzy sformułowali koncepcje kultur zachowawczych i kultur progresywnych, a ponadto sporządzili listę czynników bezpośrednio warunkujących rozwój lub zacofanie określonych państw ${ }^{35}$. W kulturach zachowawczych ludzie żyją w nędzy, niesprawiedliwości i przemocy, podczas gdy w kulturach progresywnych sa motywowani do pomnażania swego majątku, do kształcenia się oraz do pełnego, indywidualnego rozwoju własnej osobowości $\mathrm{w}$ otoczeniu przejrzystych i sprawiedliwych zasad. Czynniki, które sa odpowiedzialne za postęp cywilizacyjny (Grondona wymienia ich aż dwadzieścia ${ }^{36}$, Harrison dziesięć) dotyczą głównie reguł i prawidłowości pozwalających swobodnie się kształtować gospodarce rynkowej, nakazujących poszanowanie praw człowieka i generalnie wiążących się $z$ powstawaniem demokratycznego społeczeństwa.

Można zatem stwierdzić, iż rad, w jaki sposób uzdrowić gospodarkę i społeczeństwo w Ameryce Łacińskiej, nie brakuje. Trzeba jednak pamiętać, że miliony ludzi żyjące w nędzy i przyzwyczajone do bierności, podobnie jak inne specyficznie problemy latynoamerykańskie, stanowią wyzwania, do których niełatwo jest dopasować ogólnikowe wskazówki, które sprawdziły się na przykład w Azji Południowo-Wschodniej. Potrzeba bowiem niekiedy wielu lat, aby liberalna demokracja zapuściła trwałe korzenie w danym państwie

\footnotetext{
${ }^{35}$ Por. M. Grondona: Kulturowa typologia rozwoju gospodarczego, w: L.E. Harrison, S. Huntington (red.): Kultura..., s. 105-113 oraz L.E. Harrison: Upowszechnianie pozytywnych zmian kulturowych, ibidem, s. 434-436.

${ }^{36}$ Grondona omawia następujące, które sa odmiennie postrzegane w zależności od tego, czy dana kultura sprzyja, czy też sprzeciwia się rozwojowi (co najlepiej widać przez pryzmat wydajności ekonomicznej poszczególnych kultur): religia, wiara w jednostkę, imperatyw moralny, dwa wymiary bogactwa, wolna konkurencja, sprawiedliwość społeczna, wartość pracy, rola herezji, edukacja, znaczenie użyteczności, cnoty mniejsze, wymiar czasowy, racjonalność, władza, światopogląd, pogląd na życie oraz na zbawienie, rodzaje utopii, optymizm i wizja demokracji. Por. M. Grondona: Kulturowa typologia..., s. 105-113.
} 
oraz przyniosła jego obywatelom rzeczywista korzyść i godność. Jako mieszkańcy Europy Środkowo-Wschodniej potrafimy jednak doganiać pod względem swobód obywatelskich oraz charakteru gospodarek Wielka Brytanię, Francję i Niemcy. Dlatego - niewątpliwie również ogromny - potencjał ludzki Ameryki Łacińskiej wciąż czeka jedynie na sprzyjajace jego rozwojowi warunki kulturowe oraz odpowiedzialnych polityków, którzy będą umieli wyzwolić większa przedsiębiorczość u spadkobierców dawnych cywilizacji indiańskich i kolonialnego dziedzictwa hiszpańsko-portugalskiego.

Nie zapominajmy również o tym, że różnice kulturowe sa także istotna wartością i nie powinniśmy nikogo namawiać do natychmiastowego porzucania swoich tradycji i upodobań oraz do przejmowania hurtem obcych, nieznanych mu wzorów życia, w imię jakiegoś zakrojonego na szeroka skalę „oświecania publicznego”. To bardzo dobrze, że Meksyk, Rio de Janeiro i Lima maja odmienny urok od Nowego Jorku, Chicago czy Montrealu. Nikt również raczej nie odważyłby się twierdzić, że obecna kultura latynoamerykańska - jako taka - wymaga zastapienia przez jakąś zupełnie nową, ponieważ chodzi jedynie o ukazanie tych jej elementów, które potrzebuja przemyślenia i przebudowy w świetle zmian zachodzących w globalnej gospodarce. Przykład Japonii, a ostatnio także coraz bardziej Chin, pokazuje aż nadto wyraźnie, jak elastyczne potrafią być rodzime kultury $\mathrm{w}$ adaptacji obcych sobie tradycji edukacyjnych czy rynkowych. Te nowe tradycje moga bowiem, w ostatecznym wyniku, przyczynić się do ogólnego wzrostu świadomości społecznej, zadowolenia i dumy $z$ własnego narodu oraz pomnożenia jego dobrobytu. Skoro zaś Azjaci potrafili imponująco przebudować własna cywilizację, czerpiąc inspirację z Zachodu, a Polacy, Czesi i Węgrzy coraz odważniej rywalizuja z krajami „starej Unii”, wiele wskazuje na to, że również Ameryka Łacińska nie powiedziała jeszcze ostatniego słowa na drodze do postępu cywilizacyjnego $\mathrm{w}$ gospodarce i rozwoju społecznym.

Wizja zjednoczenia Europy, Ameryki Północnej i Ameryki Południowej w jeden organizm - jednolity społecznie, ideologicznie lub 
tym bardziej politycznie - wydaje się dziś zarówno bardzo odległa, jak i po prostu fantastyczna. Gdy chodzi jednak o wartości, tradycje i zwyczaje akceptowane $\mathrm{w}$ tych częściach świata, trzeba stwierdzić, że mimo dzielących je różnic kulturowych mamy raczej solidne podstawy do twierdzenia o jednym, zachodnim świecie (tym bardziej że do cywilizacji Zachodu Huntington zalicza jeszcze wszystkie państwa założone i skolonizowane przez Europejczyków, także Australię i Nową Zelandię). A jedność cywilizacyjna skłania, mimo wszystko, do poszukiwania współpracy i wzajemnego zrozumienia wobec poważnych problemów, ostatnio zwłaszcza gospodarczych - które ze względu na wspólną historię i tradycje - maja zbliżony przebieg $\mathrm{w}$ każdym $\mathrm{z}$ tych państw. 